\title{
Autosomal recessive cutis laxa type 2A
}

INSERM

\section{Source}

INSERM. (1999). Orphanet: an online rare disease and orphan drug data base. Autosomal recessive cutis laxa type 2 A. ORPHA:357058

A rare, genetic, dermis elastic tissue disease characterized by redundant, overfolded skin of variable severity, ranging from wrinkly skin to cutis laxa associated with pre- and postnatal growth retardation, hypotonia, mild to moderate developmental delay, late closure of anterior fontanelle, and craniofacial dysmorphism (including microcephaly, hypertelorism, downslanting palpebral fissures, large, prominent nasal root with funnel nose, small, low-set ears, long philtrum, drooping facial skin). Additional manifestations may include seizures, intellectual disability, congenital hip dislocation, inguinal hernia, and cortical and cerebellar malformations. Pretibial pseudo-ecchymotic skin lesions have occasionally been associated. 